\title{
Structural Studies of Curcuminoids. VI. Crystal Structure of 1,7-Bis(4-hydroxyphenyl)-1,6-heptadiene-3,5-dione Hydrate
}

\author{
J. Karlsen, ${ }^{a}$ A. Mostad ${ }^{b}$ and H. H. Tønnesen ${ }^{a}$

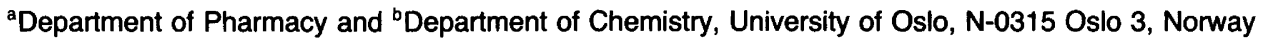

\begin{abstract}
Karlsen, J., Mostad, A. and Tønnesen, H. H., 1988. Structural Studies of Curcuminoids. VI. Crystal Structure of 1,7-Bis(4-hydroxyphenyl)-1,6-heptadiene-3,5-dione Hydrate. - Acta Chem. Scand., Ser. B 42: 23-27.

The crystal and molecular structure of 1,7-bis(4-hydroxyphenyl)-1,6-heptadiene-3,5-dione hydrate (BISDEM) has been determined at low temperature (122 K) by X-ray crystallographic methods using 1746 reflections. The crystals are monoclinic, space group $P 2_{1} / c$ with unit cell dimensions $a=6.971(1), b=$ 7.503(1), $c=30.807(5) \AA$ and $\beta=91.66(2)^{0}$. The structure was refined to a conventional $R$-factor of 0.041 . The molecular structure as well as the molecular packing in the crystals of the title compound are found to be almost identical to those reported for the methanol solvate of the curcumin derivative.
\end{abstract}

The title compound is a natural product that has been studied previously in this laboratory in the form of a methanol solvate. ${ }^{1}$ In an effort to exclude solvent molecules from the crystals, different solvents were used for recrystallization; crystals which appeared to be promising were obtained from ethanol. It subsequently turned out that the crystals contained water molecules, but the hydrate presented an opportunity to study the curcuminoid molecules in a crystal environment different from that of the methanol solvate. A structural study was therefore carried out.

\section{Experimental}

Orange-yellow crystals of the title compound were obtained by recrystallisation from ethanol. Crystal and experimental data are given in Table 1. Three test reflections were measured periodically at intervals of $\mathbf{1 3 5}$ measurements during the intensity data collection; no loss of intensity was found. Standard deviations in the measured intensities were calculated as $\sigma(I)=\left[C_{\mathrm{T}}+\right.$ $\left.\left(0.02 C_{\mathrm{N}}\right)^{2}\right]^{1 / 2}$, where $C_{\mathrm{T}}$ is the total number of counts and $C_{\mathrm{N}}$ is the scan count minus the background count. Corrections were made for Lorentz and polarisation effects. Unit cell dimensions were determined from diffractometer setting angles of 25 reflections. The coordinates of all non-hydrogen atoms were determined by di-
Table 1. Crystal and experimental data.

\begin{tabular}{|c|c|}
\hline $\begin{array}{l}\text { Compound } \\
\text { Diffractometer }\end{array}$ & $\begin{array}{l}\mathrm{C}_{19} \mathrm{H}_{16} \mathrm{O}_{4} \mathrm{H}_{2} \mathrm{O} \\
\text { NICOLET P-3/F }\end{array}$ \\
\hline Crystal size/mm & $0.35 \times 0.25 \times 0.15$ \\
\hline Radiation & MoKa \\
\hline Crystal system & Monoclinic \\
\hline$a / \AA$ & $6.970(1)$ \\
\hline$b / \AA ̊ A$ & $7.503(1)$ \\
\hline$c / \AA ̊$ & $30.807(5)$ \\
\hline$\beta /{ }^{\circ}$ & $91.66(2)$ \\
\hline$V / \AA^{3}$ & 1610.5 \\
\hline Temp./K & 122 \\
\hline Space group & $\mathrm{P}_{1} / c$ \\
\hline M & 326.2 \\
\hline$Z$ & 4 \\
\hline$F(000)$ & 688 \\
\hline$D_{x} / \mathrm{g} \mathrm{cm}^{-3}$ & 1.345 \\
\hline$\mu(\mathrm{MoK \alpha}) / \mathrm{cm}^{-1}$ & 1.0 \\
\hline Scan mode & $\omega$ \\
\hline Scan speed $(2 \theta) / / \min ^{-1}$ & 3.0 \\
\hline Scan range $(2 \theta) \rho$ & 1.1 \\
\hline Maximum $\sin \theta / N / \AA^{-1}$ & 0.59 \\
\hline No. of indep. meas. & 3129 \\
\hline No. with $I>3 \sigma(I)$ & 1740 \\
\hline Method used to solve structure & MITHRIL \\
\hline No. of parameters refined & 304 \\
\hline$R=\Sigma\left|F_{0}-F_{c}\right| / \Sigma F_{0}$ & 0.040 \\
\hline$R_{w}=\left[\Sigma w\left(F_{o}-F_{c}\right)^{2} / \Sigma w F_{o}^{2}\right]^{1 / 2 a}$ & 0.039 \\
\hline$S=\left[\Sigma W\left(F_{0}-F_{c}\right)^{2} /(n-m)\right]^{1 / 2}$ & 1.5 \\
\hline
\end{tabular}

${ }^{a} W$ is the inverse of the variance of the observed structure factors. 
Table 2. Fractional atomic coordinates for BISDEM. Estimated standard deviations in parentheses.

\begin{tabular}{lrrll}
\hline Atom & \multicolumn{1}{ll}{$y$} & \multicolumn{1}{l}{$z$} & $U_{\text {eq }}{ }^{2}$ \\
\hline O1 & \multicolumn{1}{l}{$1.7987(3)$} & $-0.3793(3)$ & $0.5107(1)$ & 0.042 \\
O2 & $0.7861(2)$ & $0.1141(3)$ & $0.5913(1)$ & 0.033 \\
O3 & $0.5052(2)$ & $0.1545(3)$ & $0.6394(1)$ & 0.035 \\
O4 & $-0.1626(2)$ & $-0.0020(3)$ & $0.8563(1)$ & 0.040 \\
O5 & $1.0022(3)$ & $0.3966(3)$ & $0.5652(1)$ & 0.039 \\
C1 & $1.6297(4)$ & $-0.3151(4)$ & $0.5261(1)$ & 0.034 \\
C2 & $1.5923(4)$ & $-0.3214(4)$ & $0.5703(1)$ & 0.036 \\
C3 & $1.4240(4)$ & $-0.2492(4)$ & $0.5850(1)$ & 0.034 \\
C4 & $1.2897(4)$ & $-0.1705(4)$ & $0.5563(1)$ & 0.031 \\
C5 & $1.3320(4)$ & $-0.1682(4)$ & $0.5124(1)$ & 0.036 \\
C6 & $1.5002(4)$ & $-0.2410(4)$ & $0.4972(1)$ & 0.037 \\
C7 & $1.1141(4)$ & $-0.0864(4)$ & $0.5706(1)$ & 0.035 \\
C8 & $1.0433(4)$ & $-0.0803(4)$ & $0.6105(1)$ & 0.033 \\
C9 & $0.8617(4)$ & $0.0079(4)$ & $0.6192(1)$ & 0.030 \\
C10 & $0.7697(4)$ & $-0.0270(4)$ & $0.6589(1)$ & 0.031 \\
C11 & $0.5954(4)$ & $0.0470(4)$ & $0.6680(1)$ & 0.030 \\
C12 & $0.4972(4)$ & $0.0163(4)$ & $0.7083(1)$ & 0.031 \\
C13 & $0.3280(4)$ & $0.0925(4)$ & $0.7164(1)$ & 0.031 \\
C14 & $0.2127(4)$ & $0.0720(4)$ & $0.7549(1)$ & 0.029 \\
C15 & $0.229(4)$ & $0.1345(4)$ & $0.7532(1)$ & 0.031 \\
C16 & $-0.0989(4)$ & $0.1101(4)$ & $0.7872(1)$ & 0.032 \\
C17 & $-0.0336(4)$ & $0.0233(4)$ & $0.8245(1)$ & 0.031 \\
C18 & $0.1565(4)$ & $-0.0346(4)$ & $0.8278(1)$ & 0.030 \\
C19 & $0.2780(3)$ & $-0.0104(4)$ & $0.7935(1)$ & 0.031 \\
H2 & $1.693(4)$ & $-0.378(3)$ & $0.593(1)$ & $0.043(7)$ \\
H3 & $1.401(3)$ & $-0.262(3)$ & $0.615(1)$ & $0.038(7)$ \\
H5 & $1.241(3)$ & $-0.116(3)$ & $0.493(1)$ & $0.032(7)$ \\
H6 & $1.526(3)$ & $-0.242(3)$ & $0.464(1)$ & $0.039(7)$ \\
H7 & $1.038(3)$ & $-0.030(3)$ & $0.548(1)$ & $0.029(6)$ \\
H8 & $1.109(3)$ & $-0.142(3)$ & $0.634(1)$ & $0.034(7)$ \\
H10 & $0.826(3)$ & $-0.103(3)$ & $0.679(1)$ & $0.025(6)$ \\
H12 & $0.562(3)$ & $-0.065(3)$ & $0.729(1)$ & $0.029(6)$ \\
H13 & $0.274(3)$ & $0.175(3)$ & $0.693(1)$ & $0.030(7)$ \\
H15 & $-0.024(3)$ & $0.195(3)$ & $0.726(1)$ & $0.040(7)$ \\
H16 & $-0.232(3)$ & $0.149(3)$ & $0.785(1)$ & $0.028(7)$ \\
H18 & $0.202(3)$ & $-0.096(3)$ & $0.854(1)$ & $0.023(6)$ \\
H19 & $0.414(3)$ & $-0.055(3)$ & $0.798(1)$ & $0.038(7)$ \\
H21 & $1.864(4)$ & $-0.441(4)$ & $0.531(1)$ & $0.10(1)$ \\
H30 & $0.595(4)$ & $0.160(4)$ & $0.615(1)$ & $0.076(9)$ \\
H40 & $-0.099(4)$ & $-0.055(5)$ & $0.884(1)$ & $0.13(1)$ \\
H51 & $0.934(4)$ & $0.291(4)$ & $0.569(1)$ & $0.075(9)$ \\
H52 & $1.086(4)$ & $0.378(5)$ & $0.544(1)$ & $0.11(1)$ \\
\hline & & &
\end{tabular}

${ }^{a} U_{\text {eq }}=\left(U_{11}+U_{22}+U_{33}\right) / 3$.

rect methods. ${ }^{2}$ Refinements were performed by least-squares calculations. Hydrogen atomic positions were calculated and included in the refinements, which proceeded with anisotropic temperature factors for the heavier atoms and isotropic temperature factors for hydrogen atoms. Computer programs employed are described in Refs. 3 and 4. Final figures of merit are included in Table 1. Positional parameters are given in Table 2. Lists of anisotropic thermal parameters and structure factors may be obtained from the authors on request.

\section{Description and discussion}

A drawing of the molecule is shown in Fig. 1, where the numbering of the atoms is also indicated. Bond lengths and angles are given in Table 3 together with the corresponding values in the methanol solvate. The packing of the molecules and the hydrogen bonding is illustrated in Fig. 2. It is interesting to note that the packing of the molecules in the crystals of the monohydrate is almost identical to that found in the methanol solvate. Van der Waals contacts between molecules related by screw axes are the same in both structures; between two molecules related by a screw axis in the $y$-direction there are equal distances of $2.8 \AA$ from the oxygen atoms $\mathrm{O} 2$ and $\mathrm{O} 3$ in one molecule to the atom $\mathrm{H} 18$ in the next, and about $3.0 \AA$ from atoms $\mathrm{C} 15$ and $\mathrm{C} 16$ to $\mathrm{H} 10$; the distance between $\mathrm{O} 4$ and $\mathrm{H} 3$ is $2.6 \AA$. In the methanol solvate the molecules are linked together by three hydrogen bonds all involving the methanol oxygen atom. The water molecule in the hydrate structure is found to be engaged in the corresponding three hydrogen bonds and, in addition, one directed to the $\mathrm{O} 1$ atom. Thus, there is a slight difference in the hydrogen bond system in the two structures; in the hydrate structure there is water-linked hydrogen bonding between the layers of molecules which in the methanol solvate are connected only through van der Waals forces. As in the methanol solvate, there are no direct hydrogen bonds between the BISDEM molecules; all hydrogen bonds involve water molecules. Each water molecule is surrounded by two hydrogen donors and two hydrogen acceptors positioned in the corners of a distorted tetrahedron. Thus, the water molecule acts as a hydrogen donor to the $\mathrm{O} 2$ atom, and to the $\mathrm{O} 1$ atom in a molecule displaced by a center of symmetry. It also acts as an acceptor from $\mathrm{O} 1$ in a molecule translated one unit down the $x$-axis and one unit along the $y$-axis, and finally as an acceptor from $\mathrm{O} 4$ in a molecule acted upon by a screw axis. The geometry of the hydrogen bond- 


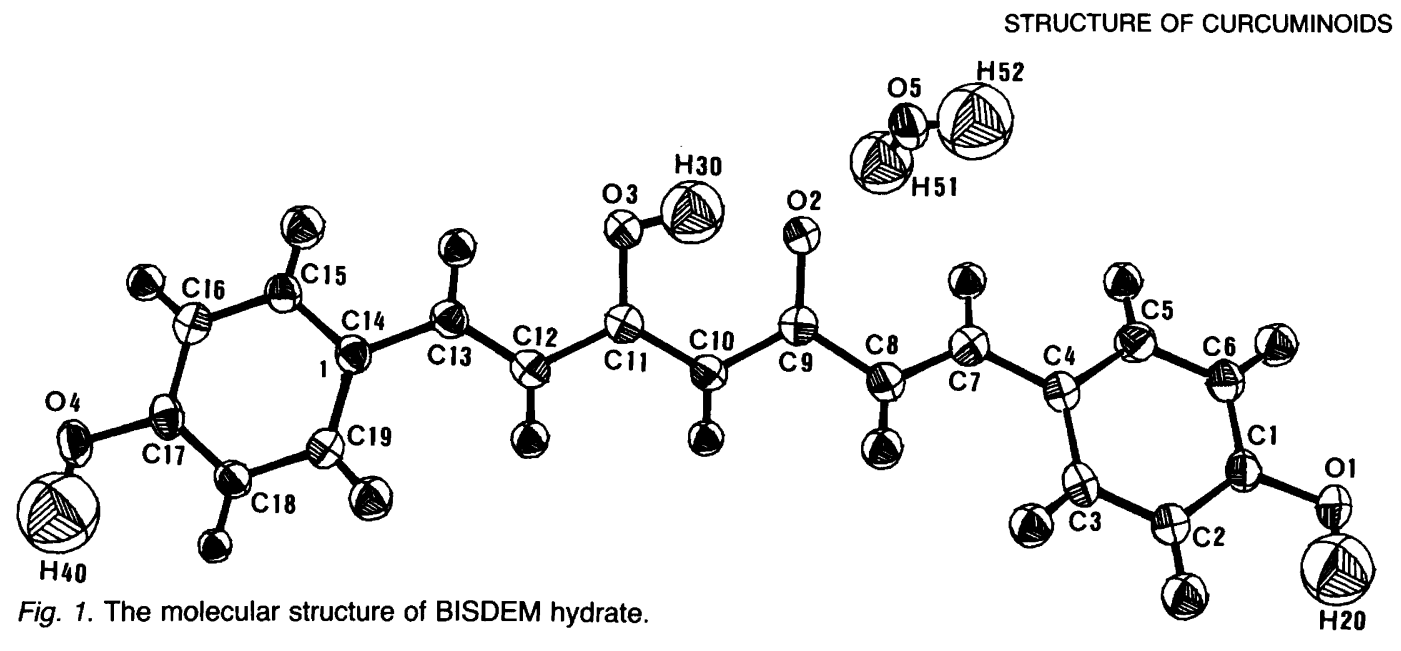

Table 3. Bond lengths $(\AA)$ and angles $\left(^{\circ}\right)$ in BISDEM in the present study $\left(\mathrm{H}_{2} \mathrm{O}\right)$ and in the methanol solvate (Meth.). Estimated standard deviations in bond lengths are $4 \times 10^{-3} \AA\left(\mathrm{H}_{2} \mathrm{O}\right)$ and $3 \times 10^{-3} \AA$ (Meth.), and in angles $0.3^{\circ}\left(\mathrm{H}_{2} \mathrm{O}\right)$ and $0.2^{\circ}$ (Meth.). The $\mathrm{C}-\mathrm{H}$ distances are all between 0.89 and $1.06 \AA$ in the hydrate structure.

\begin{tabular}{|c|c|c|c|c|c|}
\hline & $\mathrm{H}_{2} \mathrm{O}$ & Meth. & & $\mathrm{H}_{2} \mathrm{O}$ & Meth. \\
\hline \multicolumn{6}{|l|}{ Bond lengths } \\
\hline $\mathrm{O} 1-\mathrm{C} 1$ & 1.370 & 1.357 & $\mathrm{O} 2-\mathrm{C} 9$ & 1.275 & 1.283 \\
\hline $\mathrm{O} 3-\mathrm{C} 11$ & 1.336 & 1.337 & $\mathrm{O} 4-\mathrm{C} 17$ & 1.364 & 1.359 \\
\hline $\mathrm{C} 1-\mathrm{C} 2$ & 1.396 & 1.394 & $\mathrm{C} 1-\mathrm{C} 6$ & 1.367 & 1.386 \\
\hline $\mathrm{C} 2-\mathrm{C} 3$ & 1.380 & 1.377 & $\mathrm{C} 3-\mathrm{C} 4$ & 1.399 & 1.400 \\
\hline $\mathrm{C} 4-\mathrm{C} 5$ & 1.391 & 1.395 & $\mathrm{C} 4-\mathrm{C} 7$ & 1.456 & 1.455 \\
\hline $\mathrm{C} 5-\mathrm{C} 6$ & 1.388 & 1.380 & $\mathrm{C} 7-\mathrm{C} 8$ & 1.341 & 1.337 \\
\hline $\mathrm{C} 8-\mathrm{C} 9$ & 1.460 & 1.457 & $\mathrm{C} 9-\mathrm{C}_{10}$ & 1.424 & 1.421 \\
\hline $\mathrm{C}_{10}-\mathrm{C}_{11}$ & 1.375 & 1.372 & $\mathrm{C}_{11-\mathrm{C} 12}$ & 1.453 & 1.448 \\
\hline $\mathrm{C} 12-\mathrm{C} 13$ & 1.341 & 1.336 & $\mathrm{C}_{13}-\mathrm{C}_{14}$ & 1.461 & 1.459 \\
\hline $\mathrm{C}_{14}-\mathrm{C}_{15}$ & 1.403 & 1.404 & $\mathrm{C} 14-\mathrm{C}_{19}$ & 1.403 & 1.403 \\
\hline $\mathrm{C} 15-\mathrm{C} 16$ & 1.380 & 1.377 & $\mathrm{C}_{16}-\mathrm{C}_{17}$ & 1.386 & 1.388 \\
\hline $\mathrm{C} 17-\mathrm{C} 18$ & 1.395 & 1.394 & $\mathrm{C} 18-\mathrm{C} 19$ & 1.385 & 1.382 \\
\hline \multicolumn{6}{|l|}{ Angles } \\
\hline $\mathrm{O} 1-\mathrm{C}_{1}-\mathrm{C} 2$ & 120.8 & 122.2 & $\mathrm{O} 1-\mathrm{C}_{1}-\mathrm{C} 6$ & 118.5 & 118.0 \\
\hline $\mathrm{C} 2-\mathrm{C}_{1}-\mathrm{C} 6$ & 120.7 & 119.8 & $\mathrm{C}_{1}-\mathrm{C}_{2}-\mathrm{C}_{3}$ & 119.4 & 120.1 \\
\hline $\mathrm{C} 2-\mathrm{C} 3-\mathrm{C} 4$ & 121.3 & 121.1 & $\mathrm{C} 3-\mathrm{C} 4-\mathrm{C} 5$ & 117.5 & 117.6 \\
\hline $\mathrm{C} 3-\mathrm{C} 4-\mathrm{C} 7$ & 123.1 & 123.3 & $\mathrm{C} 5-\mathrm{C} 4-\mathrm{C} 7$ & 119.4 & 119.1 \\
\hline $\mathrm{C} 4-\mathrm{C} 5-\mathrm{C} 6$ & 122.0 & 121.9 & $\mathrm{C} 1-\mathrm{C} 6-\mathrm{C} 5$ & 119.2 & 119.5 \\
\hline $\mathrm{C} 4-\mathrm{C} 7-\mathrm{C} 8$ & 128.8 & 128.8 & $\mathrm{C} 7-\mathrm{C} 8-\mathrm{C} 9$ & 121.8 & 121.6 \\
\hline $\mathrm{O} 2-\mathrm{C} 9-\mathrm{C} 8$ & 120.2 & 120.2 & $\mathrm{O} 2-\mathrm{C} 9-\mathrm{C} 10$ & 120.7 & 120.4 \\
\hline $\mathrm{C} 8-\mathrm{C} 9-\mathrm{C} 10$ & 119.1 & 119.3 & $\mathrm{C} 9-\mathrm{C}_{10}-\mathrm{C}_{11}$ & 121.3 & 121.8 \\
\hline $\mathrm{O} 3-\mathrm{C} 11-\mathrm{C} 10$ & 121.0 & 120.9 & $\mathrm{O} 3-\mathrm{C} 11-\mathrm{C} 12$ & 115.7 & 116.0 \\
\hline $\mathrm{C}_{10}-\mathrm{C}_{11}-\mathrm{C}_{12}$ & 123.3 & 123.1 & $\mathrm{C}_{11}-\mathrm{C}_{12}-\mathrm{C}_{13}$ & 122.1 & 122.4 \\
\hline$C_{12}-C_{13}-C_{14}$ & 127.9 & 127.9 & C13-C14-C15 & 118.3 & 118.0 \\
\hline $\mathrm{C} 13-\mathrm{C} 14-\mathrm{C} 19$ & 124.2 & 124.6 & C15-C14-C19 & 117.5 & 117.3 \\
\hline$C_{14}-C_{15}-C_{16}$ & 121.8 & 121.8 & $\mathrm{C} 15-\mathrm{C}_{16}-\mathrm{C} 17$ & 119.8 & 119.9 \\
\hline $\mathrm{O} 4-\mathrm{C} 17-\mathrm{C} 16$ & 117.0 & 117.1 & $\mathrm{O} 4-\mathrm{C}_{17}-\mathrm{C}_{18}$ & 123.2 & 123.2 \\
\hline $\mathrm{C} 16-\mathrm{C} 17-\mathrm{C} 18$ & 119.7 & 119.7 & $\mathrm{C} 17-\mathrm{C} 18-\mathrm{C} 19$ & 120.2 & 120.1 \\
\hline C14-C19-C18 & 120.9 & 121.3 & & & \\
\hline
\end{tabular}




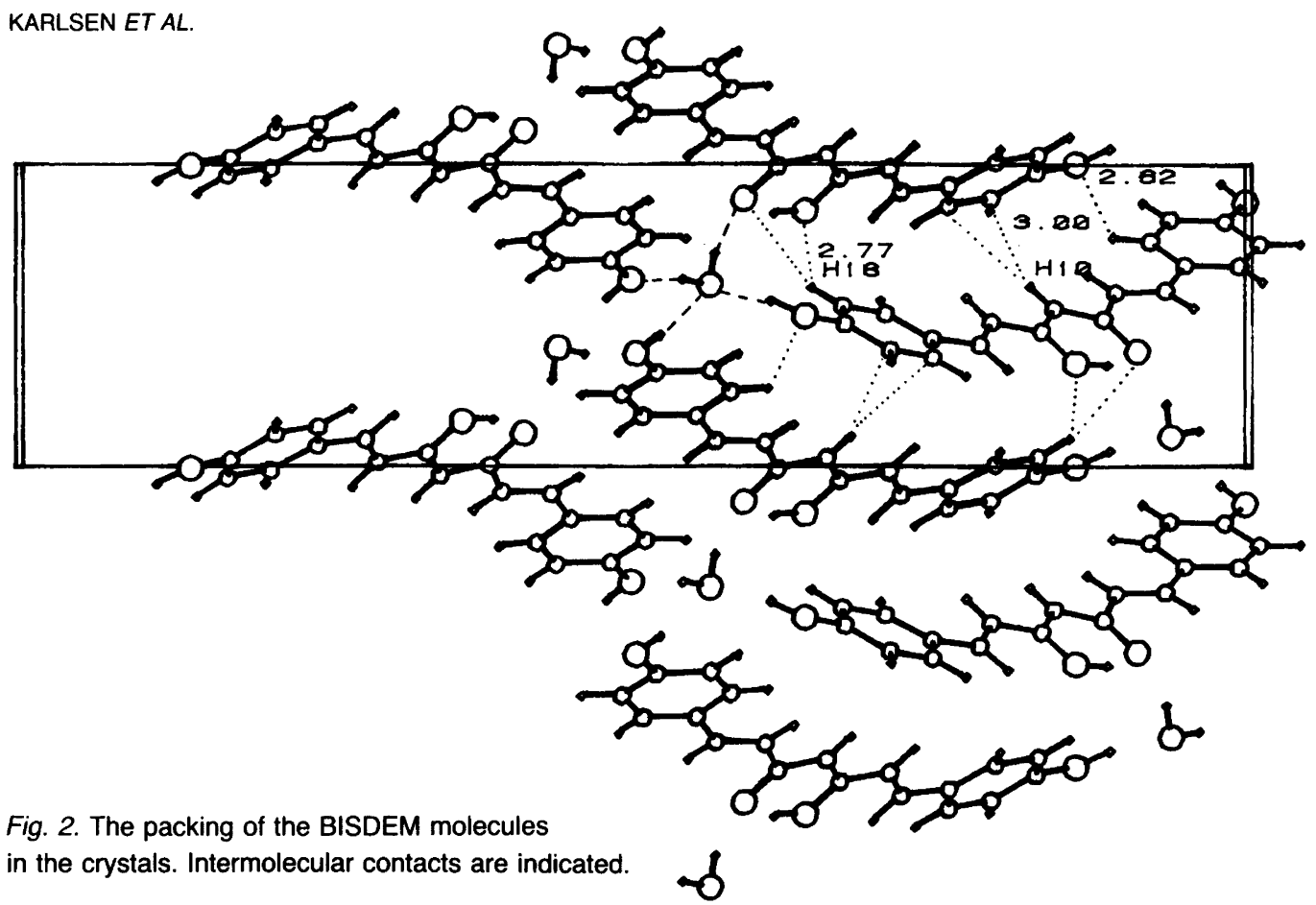

Table 4. Geometry of the hydrogen bonds in BISDEM. Distances in $\AA$, angles in ${ }^{\circ}$.

\begin{tabular}{|c|c|c|c|c|c|c|c|}
\hline D & A & & $D-A$ & $\mathrm{H} \cdots \mathrm{A}$ & $D-H \cdots A$ & $\mathrm{C}-\mathrm{O}-\mathrm{H}$ & $C-0 \cdots A$ \\
\hline 01 & O5 & $(1+x,-1+y, z)$ & 2.742 & 1.86 & 170 & 112 & 116 \\
\hline O4 & O5 & $(1-x,-1 / 2+y, 3 / 2-z)$ & 2.741 & 1.71 & 168 & 112 & 114 \\
\hline O5 & $\mathrm{O} 2$ & $(x, y, z)$ & 2.734 & 1.82 & 163 & - & - \\
\hline 05 & 01 & $(3-x,-y, 1,-z)$ & 2.758 & 1.88 & 170 & - & - \\
\hline O3 & $\mathrm{O} 2$ & $(x, y, z)$ & 2.510 & 1.57 & 154 & 103 & - \\
\hline
\end{tabular}

ing is summarized in Table 4. The similarity in the molecular packing in the hydrate and the methanol solvate is mirrored in the molecular geometry. The conformation of the BISDEM molecule is the same in the two crystal structures, as can be seen from the conformational angles in Table 5. The only significant differences is in the torsion angle about the $\mathrm{C} 4-\mathrm{C} 7$ bond, where the difference is found to be $2.8(4)^{0}$. Moreover, it is seen from Table 3 that all the bond angles are practically identical except for the $\mathrm{O} 1-\mathrm{C} 1-\mathrm{C} 2$ angle, where the difference is $1.4(4)^{0}$. Finally, there is also good agreement between bond lengths in the two structures, and the only significant differences are in the $\mathrm{O} 1-\mathrm{C} 1$ and $\mathrm{C} 1-\mathrm{C} 6$ distances. It may be noted that all the significant
Table 5. Comparison of torsion angles $\left(^{\circ}\right)$ in BISDEM hydrate and methanol solvate. Estimated standard deviations are $0.3^{\circ}$.

\begin{tabular}{lrr}
\hline Torsion angle & \multicolumn{1}{c}{$\mathrm{H}_{2} \mathrm{O}$} & \multicolumn{1}{c}{ Meth. } \\
\hline $\mathrm{C} 5-\mathrm{C} 4-\mathrm{C} 7-\mathrm{C} 8$ & 176.9 & 179.7 \\
$\mathrm{C} 4-\mathrm{C} 7-\mathrm{C} 8-\mathrm{C} 9$ & -178.9 & -179.6 \\
$\mathrm{C} 7-\mathrm{C} 8-\mathrm{C} 9-\mathrm{O} 2$ & -15.3 & -14.4 \\
$\mathrm{C} 7-\mathrm{C} 8-\mathrm{C} 9-\mathrm{C} 10$ & 164.1 & 165.8 \\
$\mathrm{O} 2-\mathrm{C} 9-\mathrm{C} 10-\mathrm{C} 11$ & 1.6 & 1.5 \\
$\mathrm{C} 8-\mathrm{C} 9-\mathrm{C} 10-\mathrm{C} 11$ & -177.8 & -178.7 \\
$\mathrm{C} 9-\mathrm{C} 10-\mathrm{C} 11-\mathrm{O} 3$ & 0.8 & 0.7 \\
$\mathrm{C} 9-\mathrm{C} 10-\mathrm{C} 11-\mathrm{C} 12$ & -179.2 & -178.9 \\
$\mathrm{O} 3-\mathrm{C} 11-\mathrm{C} 12-\mathrm{C} 13$ & -0.6 & -1.1 \\
$\mathrm{C} 10-\mathrm{C} 11-\mathrm{C} 12-\mathrm{C} 13$ & 179.4 & 178.5 \\
$\mathrm{C} 11-\mathrm{C} 12-\mathrm{C} 13-\mathrm{C} 14$ & 179.2 & 178.9 \\
$\mathrm{C} 12-\mathrm{C} 13-\mathrm{C} 14-\mathrm{C} 19$ & 11.1 & 9.9 \\
\hline
\end{tabular}


differences occur in, or in connection with, the aromatic ring which is involved, via the $\mathrm{O} 1$ atom, in the extra hydrogen bond (relative to the methanol solvate). On the other hand, all the differences except for that in the torsion angle may be explained by a displacement of the $\mathrm{C} 1$ atom.

\section{References}

1. Tønnesen, H. H., Karlsen, J., Mostad, A., Pedersen, U., Rasmussen, P. B. and Lawesson, S.-O. Acta Chem. Scand., Ser. B 37 (1983) 179.

2. Gilmore, C. F. J. Appl. Crystallogr. 17 (1984) 42.

3. Groth, P. Acta Chem. Scand. 27 (1973) 1837.

4. Mallinson, P. R. and Muir, K. W. J. Appl. Crystallogr. 18 (1985) 51.

Received July 14, 1987. 